\title{
СОВРЕМЕННЫЙ ЮВЕЛИРНЫЙ РЫНОК МИРА
}

\author{
(c) 2019 Задорина Анастасия Михайловна \\ аспирант \\ Российский государственный геологоразведочный университет \\ имени Серго Орджоникидзе, Россия, Москва \\ E-mail: carina-guseva@mail.ru
}

В статье проведен подробный анализ мирового ювелирного рынка. Изучена динамика производства драгоценных металлов в различных странах мира, а так же спрос на них.

Ключевые слова: Драгоценные металль, цена, производство, золото, серебро, платина, палладий

Состояние мировой экономики последних лет внесло определённые коррективы в ювелирные предпочтения населения всего мира. Ювелирный дизайн имеет огромное влияние не только на украшения, но и на ювелирный рынок в целом. Новый взгляд на роскошь демонстрируют многих ювелиры, разрабатывая модели брошей и подвесок из золота и серебра, с бриллиантами и цветными камнями. Матовые поверхности, золотистый, розовый, белый металл. Кольца, серьги и колье, декорированные розовыми и бесцветными бриллиантами, эмалью цвета пыльной розы и белым родием в украшениях из розового белого золота можно встретить практически в каждой ювелирной коллекции. Дизайнеры обратились к благородным фиолетовым оттенкам цвета не только потому, что он практичен и всегда на пике моды, а потому, что он самый загадочный и связанный с большим количеством легенд и историй. Шпинель, сапфиры, аметисты, кунциты и турмалины остаются фаворитами ювелирных коллекций $[1,2,3]$.

В руках ювелиров ДМ становится пластичными и принимает любые, даже самые невероятные формы. Игра воображения создает самые настоящие произведения искусства. Ювелирные изделия с камнями естественных форм - это новые интерпретации ювелирных украшений. Блеск желтого золота в очередной раз заворожил всех и завоевал ювелирные подиумы. Дизайнеры показывают коллекции, насыщенные золотисто-оранжевыми оттенками. Это самый правильный цвет для жизнерадостного настроения и атмосферы праздника. Золото не обманет, считают дизайнеры, и уверенно сочетают его с бриллиантами и жемчугом. Ювелиры часто используют зеленый цвет. Самый актуальный декор - зеленая эмаль, самые актуальные кам- ни - изумруды, сапфиры и демантоиды. Серьги, кольца и колье с изумрудами в качестве центрального камня можно было встретить практически в каждой ювелирной коллекции, представленной на выставках. Уловив тренд на смелые и вызывающе-роскошные изделия, дизайнеры создают динамичные коллекции - бусы и колье с использованием объемных, выполненных из серебра и белого золота сфер, напоминающих очаровательные модели солнечной системы. Белое золото и черный жемчуг, белое золото и черная эмаль. Можно часто встретить украшения с покрытиями черного цвета. Для этого используются изделия, декорированные бриллиантами и черными алмазами, черной и белой эмалью, черным родием в сочетании с бесцветными камнями. Очарование природы вдохновило ювелиров на создание утонченных драгоценностей из розового, белого и желтого золота. Элегантные ожерелья, колье, браслеты и кольца с китайским жемчугом, молочными кварцами и лунными камнями составляют новые линии драгоценностей. Украшения с бриллиантами - это безусловная классика, но даже в этом защищенном от невзгод сегменте существуют свои тренды: все большей популярностью пользуются ювелирные изделия с крупными и дорогими камнями. Ювелиры предлагают покупателям драгоценности как инвестиции. Бриллианты покупают все и ювелиры вовремя уловили тренд и предложили самый надежный актив, который всегда под рукой.

Доступное по цене итальянское серебро отобрало пальму первенства у более дорогостоящего золота и платины. Разноплановый аспект в отношении потребительского предпочтения «белого» или «желтого» золота: ювелирных изделий, доступных основной массе, и предна- 
значенных для повседневной носки. В этом отношении популярны костюмные украшения «костюмная бижутерия» - когда основной камень не природный, а окружающие камни природные. Из серебра делают изящные и стильные ювелирные украшения для повседневной носки и столовые приборы $[2,3,5,6]$. Спрос на высококачественное серебро, в частности на ювелирные изделия, очень высок. Рассмотрим ситуацию на мировом ювелирном рынке более подробно.

ДМ еще в древности были известны как материалы, поддающиеся художественной обработке. Никакие другие металлы не могут сравниться с ними в благородстве, долговечности, красоте. Они легко поддаются обработке и, кроме того, при необходимости их можно украсить драгоценными камнями, эмалью, чернью. Ювелиры всех времен предпочитали ДМ золото, серебро, платину и палладий другим ДМ за их красоту и удобство в работе. Их можно расплавить или, наоборот, придать им форму, чтобы воплотить любой дизайнерский замысел.

В 2017 г. мировое использование золота возросло на 10\%, а производство драгоценностей увеличилось на 13\% (2214 т), чему способствовало восстановление потребительской активности в Индии (табл. 1). В прошедшей десятилетке максимальный ювелирный спрос в 2841т был 2013 г. [7].

Производство драгоценностей в Европе было стабильно после двух последовательных лет падения и умеренное восстановление на 2\% в 2017 г. Основным фактором для этого является увеличение экономических показателей на всем континенте в целом и повышение доверия потребителей в частности. Звездой стала Россия, поскольку цена рубля снизилась, и экономика начала стабилизироваться, но даже после этого роста, производство было еще на треть ниже уровня 2014 г. На большей части Европы, включая Германию, Францию и Италию, долгосроч- ная тенденция к снижению была остановлена. Проигравшей оказалась Великобритания, где произошло сокращение производства на $18 \%$.

Производство итальянской ювелирной продукции в 80 т в 2017 г., что представляет собой маргинальный рост в годовом исчислении. В то время как статистика торговли показывает, что экспорт итальянских ювелирных изделий в прошлом году восстановился на 5\%, спрос на его крупнейший экспортный пункт назначения, а именно в ОАЭ, продолжал ослабевать третий год подряд, еще на 5\% в 2017 г. В результате доля ОАЭ от общего экспорта итальянских ювелирных изделий снизилась до 14\% в 2017 г., с 26\% в 2014 г., ставшим последним годом, когда на итальянский экспорт в Дубай зафиксирован положительный рост. Прямой экспорт ювелирных изделий из золота в Индию в прошлом году вырос более чем на 60\%, хотя в абсолютных исчислениях составляют лишь небольшую часть общего итальянского экспорта.

Производство турецких ювелирных изделий выросло на 7\% в годовом исчислении до 83 т. Импорт золота в Турции увеличился до 360 т в 2017 г. Впечатляющий рост импорта был в основном создан производителями ювелирных изделий на экспорт, потому что потребление местных ювелирных изделий снизилось на $4 \%$. Экспортный сектор ювелирных изделий пользовался впечатляющим успехом и увеличился в стоимостном выражении более чем на 30\%. Поставки были в ОАЭ, Ирак, США, Гонконг и Германию.

В 2017 году российская ювелирная отрасль опубликовала двузначный процентный рост после сокращения в течение трех лет подряд, поскольку улучшившаяся экономика и стабилизировавшаяся стоимость рубля вернули спрос на золото. В период с 2000 по 2007 гг. Россия была одним из самых быстрорастущих потребителей ювелирных изделий, спрос увеличивался двуз-

Таблица 1. Производство ювелирных украшений из золота по отдельным регионам мира, тонны

\begin{tabular}{|l|c|c|c|c|c|c|c|c|c|c|}
\hline & $\mathbf{2 0 0 8}$ & $\mathbf{2 0 0 9}$ & $\mathbf{2 0 1 0}$ & $\mathbf{2 0 1 1}$ & $\mathbf{2 0 1 2}$ & $\mathbf{2 0 1 3}$ & $\mathbf{2 0 1 4}$ & $\mathbf{2 0 1 5}$ & $\mathbf{2 0 1 6}$ & $\mathbf{2 0 1 7}$ \\
\hline Европа & 533 & 328 & 312 & 301 & 291 & 301 & 331 & 287 & 255 & 261 \\
\hline Северная Америка & 108 & 90 & 90 & 81 & 73 & 75 & 79 & 83 & 82 & 83 \\
\hline Южная Америка & 39 & 32 & 36 & 30 & 30 & 32 & 36 & 28 & 26 & 26 \\
\hline Азия & 1575 & 1342 & 1576 & 1634 & 1611 & 2253 & 2047 & 2003 & 1541 & 1798 \\
\hline Африка & 96 & 71 & 57 & 51 & 59 & 62 & 63 & 59 & 46 & 43 \\
\hline Океания & 4 & 3 & 3 & 3 & 3 & 3 & 3 & 3 & 3 & 3 \\
\hline Всего по миру & 2355 & 1866 & 2083 & 2099 & 2066 & 2726 & 2559 & 2464 & 1953 & 2214 \\
\hline
\end{tabular}

Составлено автором на основе данных [7] 
начными процентными ставками, прежде чем экономика пострадала от мирового финансового кризиса [3,4]. После двух лет резкого падения, рынок ювелирных изделий из золота начал восстанавливаться при этом объемы производства выросли на 32\% за четырехлетний период, достигнув рекордного уровня докризисных лет. Однако в индустрии начался новый кризис в 2014 г. Экономика скатилась в период рецессии в 2015-16 гг., усугубленная резким снижением цен на нефть, что наряду с заметным обесцениванием рубля заставило уверенность потребителей упасть до рекордных минимумов, а местная цена на золото взлетела до беспрецедентного уровня, затронув розничные продажи золотых украшений. В результате производство ювелирных изделий столкнулось с тремя последовательными годами резкого снижения. В 2017 г. производство золотых ювелирных изделий возросло на 12\% (34 т), благодаря улучшению экономических условий и заметному снижению цены в рублевом выражении, хотя объемы остались значительно ниже уровней предыдущих лет.

Производство ювелирных изделий в Германии упало на 1\% в прошлом году до 13 т. Поскольку страна традиционно является нетто-импортером золотых украшений, достигнув в прошлом году около 4 т, потребление золотых ювелирных изделий в 2017 г. достигло 17 т. Снижение потребления золота в этом сегменте - это не столько функция снижения спроса в абсолютных единицах, сколько отражение продолжения смены карата. В прошлом году можно было заметить самую большую борьбу в 18-каратном сегменте, тогда как происходило понижение в сегменте карата, в 8 и 14-каратных сегментах зарегистрировано значительное увеличение [1,7].

Общее использование золота в Северной Америке упало на 17\% в прошлом году до 206 т, что является самым низким показателем за последние два десятилетия. Но производство ювелирных изделий увеличилось на 1\% до 83 т. Изготовление ювелирных изделий стало самым большим вкладом в общий объем прибыли прошлого года. С укреплением импорта розничное потребление ювелирных изделий в Северной Америке также выросло на 5\% до 167 т. Ювелирный сектор в США улучшался с ростом доходов. Свадебный сектор продолжал демонстрировать силу и наблюдался быстрый рост спроса на синтетические алмазы. Почти половина этого спроса обслуживалась импортом, который уве- личился на 69 т впервые с 2008 г, по сравнению с внутренним изготовлением. Из четырех ведущих стран импортёров, на долю которых приходится 53\% всего импорта США, Италия или Турция, зафиксировано значительное увеличение на 27\% и 21\% соответственно, Индия, ответственная за 16\% поставок золотых ювелирных изделий, сократился поставки на 6\%, импорт из Китая оставался на прежнем уровне.

На индийском субконтиненте в 2017 г. производство ювелирных изделий увеличилось до 58\%, а их потребление - на 35\%. Импорт 30лота в Индию возрос на 72\% и составил 880 т. Изготовление ювелирных изделий выросло до второго по величине рекордного уровня в 718 т. Изготовление ювелирных изделий в КНР, на долю которых приходится 68\% общего спроса на золото в Китае, снизилось на 3\% до 674 т в 2017 г. Это было четвертое снижение с пика в 2013 г., и было на 43\% ниже этого уровня. Ювелирные изделия - это сегмент, у которого самый большой объём золота в Китае, что ежегодно составляет более двух третей всего золотого спроса. Тем не менее, после падения на $17 \%$ среднегодового спроса за 2013-2016 гг., похоже, что ювелирный сектор может окончательно стабилизироваться $[4,7]$. Учитывая, что вся китайская ювелирная индустрия переживает ряд спадов и подъёмов с 2013 г., производители пытаются найти следующую актуальную тенденцию, поскольку интерес рынка золотым продуктам высоко каратной пробы снижается [1]. В связи с этим, были разработаны и протестированы новые рыночные продукты: изделия из золота 375 пробы, но они не прижились на рынке. Спрос на изделия из чистого золота (999,9 пробы), остающийся доминирующей формой золотых ювелирных изделий, продолжал лидировать с 2013 г. С другой стороны, сегмент 750 пробы (K-gold) усилил популярность в последние годы [1]. Популярный цвет в данном сегменте был желто-золотой, отражающий историческую близость к желтому цвету общей китайской культуры. Но со временем, цвет не устроил покупателей и изготовители ввели изделия из золото 950 пробы в конце 2016 г., и это мгновенно стало хитом. Изделия из золото 950 пробы могут быть менее сложным по сравнению с изделия из золото 750 пробы, более высокая чистота золота обычно способствует желто-золотому цвету сохраняться. Таким образом, изделия из золото 950 пробы стали де-факто для ювелирных продуктов из желтого золота, в то 
время как розовое золото стало основным сегментом для изделия из золото 750 пробы. Белое золото остается относительно менее популярным среди ювелирных изделий в китайской культуре. В 2017 г. было использовано 75 тонн золота для изготовления изделий из золото 750 пробы и ювелирных изделий из золото 950 пробы. Это составило $11 \%$ рынка.

Еще один сегмент, который в последние годы также быстро растет,- трехмерное (3D) твердое золото. Большая часть этих изделий трехмерного твердого золота по-прежнему составляет изделия из золото 999,9 пролбы. Большая часть 3D изделий означает, что продукты могут быть большими по размеру, но все же очень легкими (при этом стоить меньше), удовлетворяя потребности покупателей. Общий объем изделий из трехмерного твердого золота за последние годы вырос более чем в 10 раз, в основном из-за очень низких начальных затрат и совершенствования методов, которые привели к улучшению конечных продуктов. В настоящее время более 80\% 30лотых подвесок является продуктом 3D твердого золота. Выпуск золотых колец, серёжек и браслетов также увеличивается. Полагают, изделия из 3D твердого золота потребляет на 50-75\% меньше золота, чем продукты из чистого золота, что помогает экономить металл [7]. В 2017 г. объем продукции из 3D твердого золота вырос примерно на $35 \%$, а общий объём металла в этом сегменте составляет 10\% общего использования золота в ювелирных изделиях.

В странах Юго-Восточной Азии производство ювелирных изделий упало всего на $2 \%$ в прошлом году до 866 т, четвертое снижение подряд и самый низкий уровень с 2012 г. Вьетнам был в списке победителей, потребление там растет пятый год подряд; потребители обращаются к изделиям из золото 950 пробы в качестве средства хранения богатства. В Сингапуре, Индонезии и Малайзии отрицательно повлияло падение спроса на экспорт, последний снизился на $11 \%$. Потребление ювелирных изделий упало в Тайланде за последний год более чем на 9,2\% по сравнению с 2016 г. Брак и свадьбы являются одним из основных традиционных усилителей спроса на золото в Тайване, и снижение числа браков значительно сократило общий спрос на ювелирные изделия. Кроме того, возникла тенденция брать в аренду наборы золотых украшений для свадьбы, что снизило потребление золотых украшений.
Основным направлением ювелирной индустрии Гонконга было расширение их целевых клиентов до более молодого поколения. Оно требует более модных и «персонализированных» продуктов, что относится к продукции, отличной от прочих. Доля рынка ювелирных изделий К-золота также растет, поскольку этот сегмент предлагает больше вариантов выбора цвета и дизайна. Таиланд в 2017 г. снизили производство золотых изделий на 9\% [7].

В Японии потребление ювелирных изделий оставалось относительно низким, снизившись на 3\% до 19,1 т. Сокращение на рынке 3олота было наиболее острой для белых изделия из золото7950 пробы, хотя желтое золото также пострадало. Одним из сегментов рынка при регистрации прибыли в прошлом году являлся рынок ювелирных изделий из золото 375 пробы более низкой чистотой золота, которые начали пользоваться популярностью среди молодежи.

Потребление индонезийских ювелирных изделий увеличилось с 6\% -ным ростом в 2017 г. В то время как потребление ювелирных изделий вернулось к росту, стоит отметить серьезное сокращение производства ювелирной промышленности за последнее десятилетие. В 2008 г. потребление индонезийских ювелирных изделий составило около 60 т, годовой объем внутреннего потребления достиг 36 т. Основные регионы назначения экспорта зафиксировали двузначный процентный рост, в особенности на Ближнем Востоке и Юго-Восточной Азии. Экспорт в другие регионы взлетел в 2013 г. на 40\% во многом благодаря значительному росту поставки серебряных ювелирных изделий в Гонконг - самый большой рынок в этом регионе [4,7]. 27\%-ный рост экспорта на Ближний Восток объясняется высоким уровнем потребления серебряных изделий в Объединенных Арабских Эмиратах. Малайзийское потребление золота уменьшилось на 7\% в 2017 году, а изготовление ювелирных изделий - на $11 \%$ по мере падения экспорта. Сектор, ориентированный на экспорт, боролся, поскольку спрос на Ближний Восток, в Индию и Китай резко снизился с недавнего пика в 2013 году. Кроме того, введение 6\% НТУ 1 апреля 2015 года оказало непосредственное влияние на внутреннее потребление, что привело к местному оттоку в этом году на 27\%. В 2017 г. баланс на экспортных рынках был хрупким, но внутреннее потребление увеличилось, хотя и временно, из необычного источника; за счет своего рода 
пирамидной схемы. Производство ювелирных изделий в Пенанга упало на $11 \%$, составив 30 т. Наибольшее снижение было замечено на крупнейшем рынке малазийского экспорта в Дубае, где спрос быстро упал после введения от 5\% -ной пошлины на импорт ювелирных изделий в начале прошлого года. Хотя спрос в Дубае был слабым, региональные рынки в Саудовской Аравии и Ираке, в частности, несли меньшие, чем в прошлом году, потери. Ярким пятном стал в прошлом году Сингапур, при этом значительная часть 22-кар. изделий попадала в Индию через нелегальные каналы. Экономика Малайзии продолжала успешно функционировать с более высоким, чем ожидалось, ростом на 5,8\% в 2017 г. но спрос на золотые украшения был не высоким. Средняя цена на золото в местной валюте подскочила на 5\%, и это, вероятно, сильно повлияло на объемы потребления.

В то время как потребление ювелирных изделий восстановилось за прошлый год, изготовление ювелирных изделий в Индонезии оставалось неизменным, в основном в результате ослабления экспортного сектора. Большинство потоков, выходящих из Индонезии, направлялись в Гонконг (для китайского рынка) или в Дубай, который затем реэкспортировал поток в близлежащие страны ССЗ. В прошлом году потребление в ОАЭ было слабым, спрос со стороны оптовых торговцев в Дубае был в лучшем случае очаговым в связи со снижением цен из-за конкуренции. Эта тенденция оказала значительное влияние на индонезийских производителей с поправкой на сообщения об отклонениях с уменьшением количества сообщений об отклонениях в размере 50\% [7].

Рынок золота во Вьетнаме в течение последних пяти лет частично блокировался после решения правительства приостановить импорт золота и жестко контролировать доступ потребителей к драгоценным металлам через ряд законодательных изменений, которые ограничивали продажу и распределение инвестиционных слитков. В мае 2012 г. правительство Вьетнама ввело новое законодательство о торговых операциях по управлению золотом. С тех пор потоки золота в страну с населением почти 93 млн. поступали почти полностью из неофициальных источников. В последние годы эти потоки достигли 85 т за один год и поступали из Камбоджи и на материковую территорию Китая. Рынок ювелирных изделий во Вьетнаме увеличился на
7\% и достиг е, чем в прошлом году, до 16,8 т. Внутренняя экономика растет с ростом ВВП на 6,8\% в 2017 г., а также снижением инфляции с 4,7\% в 2016 г. до 2,6\% в 2017 г., причем это расширение привело к росту доходов и улучшению потребительских расходов. В последнее время наблюдается заметное потребление золота и переход на ювелирные изделия в 24 кар. как средство экономии $[4,7]$.

Потребление ювелирных изделий на Ближнем Востоке возросло на 8\% в 2017 г. до 309,4 т после резкого падения в 2016 г. Спрос в ОАЭ возрос на 13\%, несмотря на ввеление налога на товары и услуги (НТУ) в этом году. Отмечено падение на рынках в Саудовской Аравии и Египте, причем эти рынки снизились на 24\% и $17 \%$ соответственно. Между тем, Кувейт и Бахрейн были бенефициарами более высоких издержек в Дубае из-за введенных импортных тарифов, причем оба рынка фиксируют твердую прибыль. Потребление иранских ювелирных изделий продолжает расширяться на фоне более сильного экономического роста и большей политической стабильности. Наибольшее влияние было оказано на изделия из 21- кар. золота, которые пользуются основным спросом, хотя 18-кар. изделия улучшили показатели спроса, поскольку они нацелены на менее чувствительный к ценам рынок. Иран увеличил производство изделий из золота на 13\%, второй по величине показатель в течение многих лет. Потребление ювелирных изделий в Кувейте возросло, после двух последовательных спадов, подскочив на 12\% до 22,6 т. Спрос на алмазы и ювелирные изделия из 30лото 750 пробы набирал обороты, но и спрос на изделия из золото 950 пробы сильно поднялся. В Иордании потребление ювелирных изделий в прошлом году оставалось относительно стабильным, что всего лишь на 2\% выше по сравнению с уровнем 2016 г. В других странах, Бахрейне и Катаре годы были совсем разными, в первом наблюдалось годовое увеличение на 21\% [7].

Потребление ювелирных изделий в Саудовской Аравии сократилось на 24\% до 29,0 т, что составляет лишь часть его прежней славы. Действительно, в начале тысячелетия отток Саудовской золотой ювелирной продукции составлял почти 170 т в год. Особенностью рынка в последние годы стал переход на изделия из золота 750 пробы (с рынка, на котором преобладали изделия из изделия из золото 850 пробы) и значительно упростились до более простых дизайнов. 
Эта тенденция продолжалась в течение 2017 г. с ростом производства 3D-ювелирных изделий, внося вклад в обвал поставок чистого золота. В 2017 г. спрос на инвестиции также снизился, снизившись на 17\% до 9,3 т, десятилетний минимум. На отсутствие ожидания повышения цен и сокращения потребительской экономики приходится большая часть падения. Импорт слитков был перекрыт потоками из ОАЭ с прямыми поставками из Швейцарии, снизившись на $85 \%$ по сравнению с предыдущим годом [7].

За прошедшие 10 лет общемировое производство ювелирных украшений из серебра увеличилось на $18 \%$ в основном за счет азиатских стран, увеличивших производство серебряных украшений на $30 \%[5,8]$. Страны Северной и Южной Америк увеличили производство ювелирного серебра на 29\%, а Австралия и Океания - на 40\%. Снижение производства наблюдалось в Европе - на $20 \%$ и Африке - на $30 \%$. Среди стран, увеличивших производство серебряных ювелирных украшений - США и Мексика, где производство выросло на $33 \%$ и $29 \%$ соответственно, а также Индонезия, Япония и Вьетнам, увеличившие производство на $75 \%, 17 \%$ и $64 \%$ соответственно (табл.2).

Остальные мировые державы, несмотря на относительно высокий уровень производства подверглись снижению его объемов. Таким образом, 10 лет назад Италия крупнейший поставщик ювелирного серебра в Европе, выпускала 703 т серебряных украшений, занимая 3-е место в мире после Китая и Таиланда. Сейчас страна, производя на 16\% меньше (590 т), занимает 4-е место в мире, уступая таким азиатским странам, как Индия, Китай и Таиланд. В свою очередь Китай и Таиланд, выпуская 1121 т и 904 т ювелирных украшений соответственно, спустились на одну строку ниже в рейтинге стран-лидеров, снизив производство на $26 \%$ и $28 \%$ [8].
Производство ювелирных украшений из серебра в России за 10 лет снизилось на $60 \%$. В 2008 г. страна занимала 11 место, в 2010 г. Россия увеличила производство до максимального уровня - 104 т, занимая по-прежнему 11 место, а в 2017 г.- опустилась на 1 позицию, выпустив 60 т ювелирного серебра. Производство ювелирных украшений из серебра в России в 2016 г. упало на $13 \%[4,8]$.

Страны Южной Америки, напротив, увеличили производство серебра с 144 т в 2005 г. до 231 т в 2013 г. Однако с тех пор страны снижают производство посуды и ювелирных изделий из серебра год за годом, показав в 2016 г. результат -183 т. Основными странами-производителями серебра здесь являются Бразилия, Доминиканская Республика и Перу [8].

Ежегодное увеличение объема производства произошло благодаря 35\%-ному росту в 2013 г. и отражает низкие цены на серебро и улучшающуюся экономическую ситуацию в промышленно развитых странах, что повысило ожидания потребителей и, соответственно, розничную торговлю.

Что касается азиатского континента, то здесь наблюдается увеличение производство серебра, в особенности в Индии, которая является одним из основных импортеров столового и ювелирного серебра во многие страны мира. Ювелирные украшения из белого драгоценного металла из Индии, дополненные натуральными камнями различных форм и расцветок приобретают бо́льшую популярность с каждым годом. За десять лет страна увеличила производство серебра почти в три раза. Это объясняется повышением спроса на серебро в 2013-2014 гг. в связи с повышением цен на золото и снижением цен на серебро. 2015 г. ознаменовался самым высоким результатом в истории Индии -3539 т ювелирных украшений и посуды из серебра, однако уже на

Таблица 2. Производство ювелирных украшений и столовых приборов из серебра по отдельным регионам мира, тонны

\begin{tabular}{|l|c|c|c|c|c|c|c|c|c|c|}
\hline & $\mathbf{2 0 0 8}$ & $\mathbf{2 0 0 9}$ & $\mathbf{2 0 1 0}$ & $\mathbf{2 0 1 1}$ & $\mathbf{2 0 1 2}$ & $\mathbf{2 0 1 3}$ & $\mathbf{2 0 1 4}$ & $\mathbf{2 0 1 5}$ & $\mathbf{2 0 1 6}$ & $\mathbf{2 0 1 7}$ \\
\hline Европа & 1904 & 1754 & 1744 & 1429 & 1317 & 1318 & 1401 & 1373 & 1325 & 1340 \\
\hline Северная Америка & 838 & 745 & 772 & 847 & 797 & 884 & 948 & 981 & 950 & 1036 \\
\hline Центральная и Южная Америка & 173 & 195 & 202 & 161 & 163 & 231 & 229 & 200 & 187 & 189 \\
\hline Азия & 4319 & 4362 & 4705 & 4918 & 4829 & 6182 & 6271 & 6373 & 5457 & 5670 \\
\hline Африка & 86 & 78 & 75 & 53 & 60 & 64 & 67 & 64 & 58 & 57 \\
\hline Океания & 22 & 22 & 23 & 25 & 26 & 26 & 27 & 27 & 28 & 29 \\
\hline Всего по миру & 7342 & 7156 & 7522 & 7432 & 7191 & 8705 & 8943 & 9017 & 8004 & 8320 \\
\hline
\end{tabular}

Составлено автором на основе данных [8] 
следующий год страна сократила производство до 2945 т.

Заметно снизилось производство серебряных украшений и столового серебра и в Северной Америке. США и Канада сократили производство, но не в такой степени как Мексика. Рекордный минимум в Мексике достигнут в 2012 г., который последовал за резким спадом в 2011 г. с 400 т до 370 т, а максимум - в 2016 г., когда было произведено 527 т ювелирных изделий из серебра и серебряной посуды (последний такой результат наблюдался в 2005 г. - 511 т) [8]. Производство серебряных украшений на североамериканском континенте за 10 лет в целом выросло более чем на 200 т. В 2017 г. североамериканское производство украшений из серебра достигло рекордного уровня. Доля США в производстве серебряных украшений составляет чуть более 50\%, Мексики - 48\%, Канаде принадлежит почти 2\%. Однако, несмотря на падение производства в двух последних странах на 14\% и 10\% соответственно, США показало 12\%-ный рост производства серебряных украшений. Падение производства ювелирного серебра в Мексике отчасти объясняется снижением импорта украшений в США на 23\%. Количество импортируемых серебряных украшений в США из азиатских стран в целом снизилось, а экспорт - наоборот увеличился на $59 \%$.

На азиатском континенте наблюдается увеличение производства изделий из серебра. В частности, в Индии, которая является одним из основных импортеров столового и ювелирного серебра во многие страны мира. Ювелирные украшения из белого драгоценного металла из Индии, дополненные натуральными камнями различных форм и расцветок приобретают бо́льшую популярность с каждым годом. За десять лет страна увеличила производство изделий из серебра почти в три раза. Это объясняется повышением спроса на серебро в 2013-2014 гг. в связи с повышением цен на золото и снижением цен на серебро. Год 2015 г. ознаменовался самыми высокими результатами производства в истории Индии - 3539 т ювелирных украшений и посуды из серебра, однако уже на следующий год страна сократила его до 2945 т. Производство серебряных ювелирных украшений в Индии в 2015 г. увеличилось на $15 \%$ по сравнению с предыдущим годовым показателем и составило 2254 т. Это самый высокий результат роста, и уже третий год подряд наблюдается повышение спроса. Выпуск новой продукции преобладал над обменом старых ювелирных изделий на новые, особенно ярко это было выражено в 2011-2012 гг.- спрос увеличился с 40\% до 50\%. Несмотря на то, что серебро отличается своей доступностью, традиционно серебряные цепочки или браслеты на ногу нейтральны и с гендерной точки зрения для детей 1-3 лет, и с точки зрения дохода, так как серебро используется в Индии не только в связи с культурными убеждениями, традиционная медицина также внесла свой вклад. С этих же соображений женщины предпочитают носить одно или два кольца на пальцах ног. Кроме того, серебро является неотъемлемой частью свадебной церемонии индусов, и объем используемого серебра растет там, где уровень дохода низкий или в регионах, где серебро является основным ювелирным украшением. Серебряные цепочки 925 пробы выпускаются в Индии преимущественно для городского населения и населения посёлков городского типа. В этой сфере рынок расширился благодаря работающим женщинам.

Объемы производства серебряной посуды на протяжении 10 лет варьировались год от года [5]. Рекордный минимум был отмечен в 2012 г. 1363 т. Самый высокий показатель уровня производства был зафиксирован в 2015 г. благодаря снижению цены на металл. В 2016 г., впервые за 4 года после постепенного роста, мировое производство серебряной посуды сократилось на 17\%. Во многом такой спад обусловлен высокими ценами на серебро, в частности в странах, где местная валюта упала относительно доллара США. Самый большой спад был отмечен в Китае и Индии. В 2017 г. объемы производства вновь увеличились до 1817 т, что равно объему производства 10-летней давности [8].

Рассматривая регионы в отдельности, можно заметить снижение производства серебряной посуды на всех континентах, за исключением Азии. В отличие от Европы, Африки и американских континентов, Азия увеличила объемы производства посуды из серебра на 32,5\% во многом благодаря Индии - единственной азиатской стране, где объемы производства выросли в 2,5 раза $[4,8]$

Производство посуды в других азиатских странах подверглось снижению, в частности Китае и Таиланде - на 73\% и 60\% соответственно. При этом Китай со второго места опустился на третье, а Таиланд поднялся с пятого на чет- 
вертое. Итальянское производство серебряной посуды снизилось на $72 \%$ за прошедшие 10 лет, отодвинув страну с третьего на пятое место. Несмотря на 28\%-ный спад производства посуды из серебра, Россия поднялась с четвертого места в мировом рейтинге на 2 позиции, в а регионе вышла на первое место [2].

За это же время производство серебряных украшений и посуды в Европе сократилось почти вдвое (табл.2). Вызвано это тем, что страны континента импортируют серебряные изделия преимущественно из азиатских стран, где цена на серебро ниже европейской. Один из главных производителей серебра - Италия - снизила производство в два раза с 2005 г. что повлияло на общий объём выпуска на континенте. Турция и Германия, являясь основными игроками на рынке серебра, тоже снизили его производство, Россия наоборот увеличила производство серебряных изделий почти в два раза. Резкое увеличение было отмечено в 2007 г.

Европейское производство ювелирных украшений и столовых приборов в 2014 г. возросло на 9\% с предыдущего года, достигнув отметки в 1401 т. Это самый большой показатель региональной скорости роста. Несмотря на высокие показатели 2014 г., два последующих года принесли незначительное снижение производства, но уже в 2017 г. производство ювелирного серебра в Европе выросло на 2\% в основном благодаря Италии, которая на протяжении двух столетий является бесспорной законодательницей моды на ювелирные украшения. Именно в этой южной стране еще в начале девятнадцатого века появились первые ювелирные дома, специализирующиеся на изготовлении модных изделий из драгоценных металлов массового производства. Следование многовековым традициям, передающиеся из поколения в поколение секреты обработки металлов, постоянный поиск инновационных технологий, экспрессивность южного темперамента, фантазия и творческая неординарность - в комплексе все эти факторы сформировали хорошо узнаваемый итальянский стиль ювелирных украшений, многие годы пользующийся неизменной популярностью как у женщин, так и у мужчин.

Поставка серебряных ювелирных изделий из Италии в европейские страны выросла на $23 \%$. Повышение ожидания потребителей и низкая цена на серебро (среднегодовая цена в евро снизилась на 20\% по сравнению с предыдущим годом) привели к положительному потоку серебра на большинство рынков в данном регионе. Примечательно, что поставка серебра из Италии в Россию возросла в 2013 г. после трехлетнего спада. Это было отражением перехода от золотых 14-кар. украшений к серебряным в свете сложных экономических условий. Поставки в США увеличили объем итальянского рынка, что вызвано улучшением экономики и снижением цены серебра.

Объём мирового производства ювелирных украшений из платины за последнюю декаду приведен в табл. 3. Отметим, что предложение платины рынку за это время практически не менялось и в последний год составило 242 т, а что касается ювелирного спроса, то он изменялся в больших пределах от 57 т (2008 г.) до 93 т (2009 г.) и в 2017 г. составил 69 т.

В 2017 г. производство платиновых ювелирных изделий сократилось на 4\% до 68,6 т из-за значительного падения спроса со стороны Китая и Европы. Производство китайских платиновых ювелирных изделий сокращается четвертый год подряд, упав на 8\% в годовом исчислении до 40 т в 2017 г. Исторически ювелирный спрос Китая на платину достиг своего пика в начале 2000-х годов, когда он составлял 60 т. Но Китай и сегодня крупнейший потребитель платины в мировой ювелирной индустрии, на долю которого приходилось 58\% спроса сектора в 2017 году.

Таблица 3. Производство ювелирных украшений из платины за период 2008-2017 гг., тонны

\begin{tabular}{|l|c|c|c|c|c|c|c|c|c|c|}
\hline & $\mathbf{2 0 0 8}$ & $\mathbf{2 0 0 9}$ & $\mathbf{2 0 1 0}$ & $\mathbf{2 0 1 1}$ & $\mathbf{2 0 1 2}$ & $\mathbf{2 0 1 3}$ & $\mathbf{2 0 1 4}$ & $\mathbf{2 0 1 5}$ & $\mathbf{2 0 1 6}$ & $\mathbf{2 0 1 7}$ \\
\hline Предложение & 252,9 & 229,4 & 241,6 & 254,4 & 236,0 & 243,0 & 207,4 & 245,1 & 242,2 & 241,6 \\
\hline Спрос ювелирный & 57,4 & 93,3 & 71,2 & 75,3 & 80,7 & 85,4 & 82,8 & 80,8 & 72,1 & 68,6 \\
\hline В т.ч. Северная Америка & 6,4 & 5,6 & 6,6 & 6,8 & 7,0 & 7,3 & 7,6 & 7,7 & 7,7 & 7,6 \\
\hline Европа & 7,4 & 6,9 & 6,8 & 6,7 & 6,6 & 6,9 & 6,7 & 6,7 & 6,6 & 6,3 \\
\hline Япония & 7,7 & 8,4 & 8,1 & 8,8 & 10,0 & 10,2 & 9,9 & 10,1 & 9,9 & 9,8 \\
\hline Китай & 34,5 & 60,6 & 47,7 & 50,4 & 54,3 & 57,6 & 54,7 & 51,7 & 43,4 & 39,9 \\
\hline Другие регионы & 1,4 & 1,6 & 2,1 & 2,6 & 2,9 & 3,4 & 3,9 & 4,6 & 4,5 & 5,0 \\
\hline
\end{tabular}

Составлено автором на основе данных [6,9] 
Этому способствовал и рост ВВП Китая, который достиг впервые за семь лет 6,9\%. Но отсутствие относительного успеха в использовании объясняется тем, что китайцы имеют давнюю культурную близость к золоту, и поэтому рынок золота в Китае гораздо более развит и популярен, чем рынок платины. Китайцы имеют историческую культуру, отдавая предпочтение золотому цвету в ювелирных изделиях, большинство населения до сих пор не приняло ювелирные изделия белого цвета. Традиционные изделия из 24-кар. золота были доминирующим сегментом в ювелирном секторе, хотя и имеют розничную маржу всего $12 \%$ - 15\%. Платиновые изделия, которые обычно продаются по весу в Китае, могут вызвать рост маржи на $40 \%-50 \%$, чем можно будет воспользоваться в стратегии продаж. В последние два года китайские ювелиры переходят на производство платиновых изделий с более низкой чистотой. Китайский рынок платиновых ювелирных изделий в основном состоит из продуктов 999,9, 990,0 и 950,0 проб, причем первые два ранее занимали львиную долю рынка. Однако производители сфокусировались больше на производстве изделий робы 950,0 за последние 2 года, по мере того, как этот сегмент вытеснял с рынка другие. Изделия из платины с чистотой 950,0 стали доминантами внутри сегмента, присвоив примерно 80\% удельного веса на рынке в 2017 г.

Японское производство платиновых ювелирных изделий снизилось всего на 1\% в 2017 г. до 9,8 т, что составляет $14 \%$ от мирового объема и является самым высоким уровнем с 2007 г. [6]. Рынок платиновых ювелирных изделий превзошел золото и подорвал долю рынка белого золота, восстанавливаясь быстрее, чем большинство розничных сегментов, как только спрос начал проявлять первые признаки роста. Скромному восстановлению способствовало падение цены на платину в иене. Еще одним важным стимулом для внутренних розничных продаж в прошлом году, который помог компенсировать более глубокое снижение, стал значительный рост числа туристов, число которых достигло 28,7 млн. чел. (рост 20\%). Впечатляющий прирост был китайских туристов (15\%) и южно-корейских (40\%). Продолжали набирать обороты с наибольшим успехом интернет-продажи, а свадебный сегмент продолжает доминировать, платиновые украшения сохраняют долю рынка более $80 \%$ в нём. Платина чистотой пробы 950,0 по-прежнему доминирует на рынке, потому что широко используется в свадебном сегменте, но в настоящее время также быстро движется в сегменте моды. В результате этого сдвига спрос на изделия 850,0 и 900,0 проб снизился, причем проба 850,0 значительно сдала позиции.

Производство платиновых ювелирных изделий в Северной Америке незначительно сократилось на 1\% до 7,6 т в 2017 г. На внутреннее производство здесь приходится около двух третей розничного спроса, а на импорт приходится остаток. Фактически, в прошлом году, из-за значительного количества импортируемых платиновых ювелирных изделий в Северной Америке, розничный спрос фактически вырос на 3,6\% до 10 т, что обусловлено существенным ростом импорта платиновых ювелирных изделий на $45 \%$.

Рынок платиновых ювелирных изделий находится на стадии зарождения в Индии, но здесь растет интерес к серебряным украшениям, покрытым платиной.

Прошлый 2017 г. ознаменовался четвертым подряд годом снижения производства платиновых ювелирных изделий в Европе на 6\%. Это падение произошло, несмотря на снижение цены на платину и ее относительно низкую цену по сравнению золотом.

В табл.4 приведены данные о предложении и производство ювелирных украшений из палладия за последние 10 лет [6,9]. За это время

Таблица 4. Производство ювелирных украшений из палладия за период 2008-2017 гг., тонны

\begin{tabular}{|l|c|c|c|c|c|c|c|c|c|c|}
\hline & $\mathbf{2 0 0 8}$ & $\mathbf{2 0 0 9}$ & $\mathbf{2 0 1 0}$ & $\mathbf{2 0 1 1}$ & $\mathbf{2 0 1 2}$ & $\mathbf{2 0 1 3}$ & $\mathbf{2 0 1 4}$ & $\mathbf{2 0 1 5}$ & $\mathbf{2 0 1 6}$ & $\mathbf{2 0 1 7}$ \\
\hline Предложение & 241,7 & 236,9 & 253,0 & 266,0 & 254,2 & 256,2 & 251,3 & 266,2 & 266,3 & 278,3 \\
\hline Спрос ювелирный & 40,3 & 34,5 & 24,8 & 20,9 & 18,5 & 16,3 & 14,9 & 10,1 & 9,1 & 8,9 \\
\hline В т.ч. Северная Америка & 4,1 & 4,2 & 3,6 & 2,6 & 2,4 & 2,3 & 2,0 & 1,7 & 1,6 & 1,6 \\
\hline Европа & 4,3 & 4,0 & 4,3 & 4,5 & 4,6 & 4,7 & 4,7 & 4,7 & 4,7 & 4,5 \\
\hline Япония & 2,0 & 1,5 & 1,5 & 1,5 & 1,6 & 1,7 & 1,6 & 1,5 & 1,4 & 1,3 \\
\hline Китай & 26,0 & 20,6 & 12,5 & 10.6 & 8,4 & 6,4 & 5,3 & 0,9 & 0,1 & 0,1 \\
\hline Другие регионы & 3,9 & 4,2 & 2,6 & 1,7 & 1,5 & 1,3 & 1,2 & 1,3 & 1,3 & 1,4 \\
\hline
\end{tabular}

Составлено автором на основе данных [6,9] 
предложение палладия рынку увеличилось на 40 т, а спрос на мировую ювелирку уменьшился в 4 раза и в прошлом году составил только 8,9 т. Так, если Китай в 2008 г. использовал более 26 т металла, то в 2017 г. - только 0,1 т., а спрос на палладий в 2005 г. достиг 32 т.

Производство ювелирных изделий из палладия за последний год сократилось на 3\%. На падение в Северной Америке и Европе пришелся основной спад.

Одним из ярких сторон в прошлом году была Индия, которая увеличила объём производства на 16\% в прошлом году после роста на $11 \%$ в 2016 г. Доля Китая в общемировом объеме упала до 1\% в прошлом году, и теперь этот рынок полностью рухнул. Тем не менее, в объемном выражении именно падение потребления в Европе и Северной Америке привело к глобальному снижению, поскольку резко повысившиеся высокие цены на палладий вызвали меньший интерес у потребителей, и производители стали искать более доступные варианты легирования для ювелирных изделий из белого золота [9].

Японское производство ювелирных изделий из палладия снизилось на 5\% в прошлом году до 1,3 т, четвертое падение подряд. Палладий используется в изготовлении ювелирной продукции как компонент в сплавах как с белым золотом, так и с платиной. В 2017 г. спрос на платиновые украшения был относительно ста- бильным, но потеря доли рынка белого золота привели к снижению спроса, в то время как резко возросли цены на палладий, что также сдерживает спрос на него.

В Северной Америке ювелирные изделия из палладия упали на 3\% до 1,6 т в 2017 г. Это было восьмое годовое падение, которое возникло в основном из-за отсутствия сбыта в Соединенных Штатах. Палладий в ювелирных изделиях наиболее широко используется как сплав в золотых обручальных кольцах для получения более светлого цвета и как надежный заменитель никеля, который может вызвать раздражение кожи.

Спрос на ювелирные изделия из палладия в Европе упал в прошлом году на 6\%. Это произошло в связи с резким ростом цены на палладий, выше, чем на платину. Но увеличение продаж белого золота привело к более высокому поглощению палладия в этой области, что компенсировало некоторые потери в спросе на ювелирный каратный палладий и привело к сокращению количества продукции и переходу к изделиям 500,0 от 950,0 пробы [9].

Современный анализ мирового ювелирного рынка показал, что он имеет сложный характер «качель» как по видам ДМ и изделиям из них, так и по географии, сочетанию металлов в одном продукте и другим показателям в зависимости от предпочтений и желаний покупателей.

\section{Библиографический список}

1. Борисович В.Т. Глоссарий терминов, используемых на рынке драгоценных металлов.- М.: Золото и технологии. - 2016. - 60с.

2. Щедрова Д.А. Анализ использования серебра на мировом ювелирном рынке. Ювелирное обозрение, № 6, 2015. C. 28-30.

3. Gold Survey 2009.- London: Изд-во GFMS Ltd, 2009. 120 с.

4. Gold Survey 2015.- London: Изд-во THOMSON REUTERS, 2015. 112 с.

5. World Silver Survey 2009.- Washington: Изд-во the Silver Institute, 2009. 100 с.

6. Platinum \& Palladium Survey 2015.- London: Изд-во Thomson Reuters GFMS. 81 с.

7. Gold Survey 2018. - London: Изд-во Thomson Reuters GFMS. 94 с.

8. World Silver Survey 2018. - Washington: Изд-во the Silver Institute, 2018. 98 с.

9. Platinum \& Palladium Survey 2018.- London: Изд-во Thomson Reuters GFMS, Лондон, 76 с. 